\title{
The Viability and Potential of Smallholder Sweet Potato Enterprises as a Food Security Measure in Rural Communities of South Africa
}

\author{
Portia Ndou ${ }^{1}$, Bridget Taruvinga ${ }^{1} \&$ Christian P. du Plooy ${ }^{1}$ \\ ${ }^{1}$ Agricultural Research Council, Vegetable and Ornamental Plants, South Africa \\ Correspondence: Portia Ndou, Agricultural Research Council-Vegetable and Ornamental Plants (ARC-VOP), \\ Private Bag X293, Pretoria 0001, South Africa. Tel: 27-128-088-000. E-mail: NdouP@arc.agric.za
}

Received: December 17, 2019

Accepted: July 29, $2020 \quad$ Online Published: August 15, 2020

doi:10.5539/jas.v12n9p74

URL: https://doi.org/10.5539/jas.v12n9p74

\begin{abstract}
The Agricultural Research Council in partnership with the Department of Rural Development and Land Reform are engaged in promoting the establishment of sustainable Sweet Potato Enterprise projects in South Africa. This study sought to investigate the viability of smallholder sweet potato enterprises for the South African rural communities. Formal market surveys and Gross margin analysis were utilised in addressing the research questions. Results of the study indicate that both the sweet potato vine nurseries and growers stand a significant chance to gain considerable amount of income from sweet potato enterprises. Sweet potato vines had a gross margin of between R219,000.00 and R226,000.00 while the sweet potatoes attracted an average gross margin of $\mathrm{R} 47,000.00 / \mathrm{ha}$. Coupled with the potential to create employment and provide access to the nutritious sweet potato cultivars, sweet potato enterprises can potentially improve food security among the rural poor in South Africa, indirectly extending benefits even to those who are not directly involved in production. This study recommends support of smallholder farmers through training and infrastructure development, as well as creation of awareness among rural people of the benefits of sweet potatoes.
\end{abstract}

Keywords: food security, sweet potatoes, smallholder farming, profit, market, viability

\section{Introduction}

Issues of food security, hunger and poverty, and ways of addressing them, continue to be of great concern in South Africa. Whilst the country produces enough food to feed its population and has the capacity to import food to provide for its population, about $25 \%$ of the population is food insecure, and between $40 \%$ and $50 \%$ of people living in South Africa are at risk of hunger (Mistry, 2014; van der Berg, 2006). Food insecurity in the country is due to inadequate economic access to food by certain households in the population, rather than to a shortage of food in the country (Cloete \& Idsardi, 2012). Thus, the majority of the population lacks the financial means to obtain food, whilst food is usually wasted by those who are financially stable. It is estimated that about 13.8 million individuals in South Africa experience inadequate access to food (DAFF, 2013). In spite of relying on weather-dependant natural resources, smallholder farmers live and earn their livelihoods in the most ecologically and climatically vulnerable landscapes such as hillsides, drylands and floodplains. Smallholder farmers struggle to maintain crop yields as they confront droughts, rising sea levels and soil degradation (IFAD, 2011). In cases where productive land is available, it is not always optimally utilised for production, often for want of inputs (including finance, equipment and water) as well as skills (DAFF, 2013). The vast majority of South Africans buy their staple foods from commercial suppliers, rather than growing it themselves, and are therefore dependent on having (direct or indirect) access to cash (FANRPAN, 2006).

Poor rural households have been found to spend a larger share of their total expenses on food compared to their urban counterparts (Altman et al., 2010). Moreover, due to remote locations, food prices offered in rural areas are often inflated. In 2011, South African rural consumers paid on average R 12.06 more than urban consumers for the same food basket (Cloete \& Idsardi, 2012). Apart from utilising markets for food, certain rural households often engage in subsistence production of food, as an additional livelihood strategy, however, that does not necessarily imply that such households are more food secure (Baiphethi \& Jacobs, 2009). Agricultural production by the rural poor often gives poor yield due to poor choice of crops, lack of inputs in production and limited proficiency in production. Furthermore, smallholders produce low quantities of produce that is also of low quality owing to their inherent low resources endowment such as capital assets. In turn, high value markets 
are reluctant to deal with smallholders due to their lack of consistency in product supplies in both quantity and quality terms (Reardon, 2005). Unless there are new policy directions in agriculture, the rural poor will increasingly be forced to allocate a greater proportion of their expenditure to food, resulting in less diverse diets that are characterised by lower quality and a drop in energy intake (calories consumed) as people try to cope with the situation (Altman et al., 2010).

In order to ensure food security in the country, it is generally acknowledged that the welfare of the poor should be improved. One way towards improving the living standards of the rural people is through agricultural production and marketing (Abdu-Raheem \& Worth, 2011). In the short run, smallholder farmers operating close or below poverty datum line do not prioritise sustainable approaches without the necessary support and favourable policy environment. For instance, when farmers operating under subsistence conditions are offered the opportunity to boost yields by using chemical fertilisers, they are likely to do so if it is the best means available to feed their families. However, where the right policies and incentives are in place, smallholders have shown they will take a long term view, prioritising sustainable techniques (IFAD, 2011). It is against this background, that this paper strives to investigate if the viability of the cultivation of alternative foods like sweet potato would hold the answer to viable income generation and food security. This paper presents the argument that establishing sweet potato enterprises among smallholder farmers significantly reduces food insecurity in rural communities of South Africa. Sweet potatoes were chosen because they can be easily produced by smallholder farmers, are high yielding, their production is low risk and requires less management. Sweet potatoes can be stored in the soil and harvested when needed. Also, sweet potatoes have a wide array of health benefits, including as a source of carbohydrates $(438 \mathrm{~kJ} / 100 \mathrm{~g}$ edible portion), vitamins (with the Orange-Fleshed Sweet Potato being rich in $\beta$-carotene), minerals and dietary fiber (Laurie, 2004).

The objective of this paper is to determine how establishing sweet potato enterprises can reduce food insecurity among smallholder farmers in rural communities of South Africa, together with assessing the viability of such an intervention. The paper makes use of the Sweet potato enterprise development project to identify potential benefits of sweet potato production. The sweet potato enterprises referred to in this study are a group of 125 smallholder farmers in six provinces that were supported to commercially produce sweet potatoes.

\subsection{Background of the Sweet Potato Enterprise Development Project}

The Agricultural Research Council in partnership with the Department of Rural Development and Land Reform are engaged in promoting the establishment of sustainable Sweet Potato Enterprise projects. The programme involved the establishment of vine nurseries as well as sweet potato growers in different provinces and ensuring on-going sustainability beyond the term of the project. Sweet potato vine nurseries focus on producing sweet potato vines for replanting by sweet potato growers while the later focus on the production of the edible sweet potato tubers. The broad aim of the projects is to assist farmers to become self-sufficient and sustainable suppliers of good quality propagation material and sweet potatoes. This will in turn promote food security through ensuring own food production and income generation from sales. There are 6 provinces participating in the establishment of these projects namely, Gauteng (GP), KwaZulu-Natal (KZN), Eastern Cape (EC), Limpopo (LP), North West (NW) and Mpumalanga (MP).

The support offered by the joint institutions towards the project ranges from the production and supply of virus-free planting material to vine nurseries, distribution of planting material to growers, establishment of enterprises and mentoring together with assisting farmers to access markets. The sweet potato enterprise development project is backed up by the sweet potato improvement programme at ARC-VOPI, assessment and selection of production sites, market assessment and development, establishment of growers, assessing the viability of the enterprises and value chain analysis. Table 1 shows the distribution of the enterprises that the programme has established to date in the 6 provinces.

Table 1. Distribution of sweet potato enterprises established between 2013 and 2015

\begin{tabular}{lllllll}
\hline Province & North West & Eastern Cape & Gauteng & Limpopo & KwaZulu-Natal & Mpumalanga \\
\hline Vine nurseries & 2 & 5 & - & 2 & 4 & 1 \\
SP growers & 5 & 14 & 13 & 20 & 45 & 14 \\
\hline
\end{tabular}

ARC-VOPI is responsible for maintaining virus-free planting material and development of improved sweet potato cultivars for distribution to farmers. The improved material is distributed to vine nurseries in different provinces, who further multiply the material for further distribution to selected sweet potato growers. The 
growers then produce sweet potatoes for the market. In order to allow for the transition into entrepreneurial production, project beneficiaries obtain support in skills development, market linkages and infrastructure development and improvement.

Various policies around agriculture in South Africa can be categorised into three main focus areas, viz., improving the competitiveness of commercial agriculture in a free market dispensation, improving participation by disadvantaged communities, and protecting the natural resource base (Drimie, 2016). The sweet potato value chain has strong implications for many national policies. For instance, the strategic goal of the National Food and Nutrition Security Policy is to ensure the availability, accessibility and affordability of safe and nutritious food at national and household levels (DAFF, 2013). The essence of the policy is thus, to build on existing initiatives and systems, and putting in place mechanisms that ensure stricter alignment and better coordination. The current sweet potato value chain presents a good opportunity. The possible strategies presented herewith include efforts to increase production and distribution, increased access to production inputs by the smallholder farming sector as well as strategic use of market interventions and trade measures which will promote food security. Limited access to processing facilities or markets often associated with small-scale primary production (DAFF, 2013) can also serve as one of the critical focus areas of intervention. It is important to note that food security cannot be addressed by a single department (Drimie, 2016). The diversity of value chain players presents a need for inter-sectoral response and coordination most particularly since food security is a societal issue demanding interdependence of wide range of actors in both the formal and informal food sectors.

\section{Materials and Methods}

Two approaches were employed for the purposes of measuring the viability and potential of the smallholder sweet potato enterprises viz, market survey and gross margin analysis. In the case of market surveys, target districts and key traders were identified through consultation with Provincial-based stakeholders. A simple random sample of traders was carried out in each market, and a minimum of 100 traders were selected per province (with a total of 615 respondents). An interviewer-administered questionnaire was utilised on traders in order to collect information of market conditions and possibilities of produce from smallholder farmers entering markets. The Gross Margin analysis was used to calculate the profitability of the enterprises. The Gross Margin only took into account the costs and returns of the production. The gross margins prepared within this paper have been designed to use representative sweet potato growers from Limpopo and Eastern Cape provinces who have been in production for at least 2 seasons. The gross margin of both the vine nurseries and sweet potato growers were calculated, and compared to the values obtained from ARC-VOPI (in Gauteng province).

\section{Results and Discussion}

The results of the market survey and financial returns of sweet potatoes are discussed below. Market survey results show the different types of markets that can potentially be used by sweet potato producers and the conditions governing the markets. The results on economic returns associated with farming sweet potatoes present the financial and indirect economic benefits of establishing enterprises. The indirect economic benefits include the ability of the enterprises to create jobs and address food security, while financial benefits focus on the estimation of three attributes namely, positive cash flow from operations, positive earnings and sustainable future growth. The positive cash flows were applied in reference to the state where the farm has more money moving into the business compared to money moving out. Positive earnings in this case were used in reference to the ability of the business to do better than expected each successive season. Thus, the promotion of such smallholder agricultural enterprises corroborates the National Development Plan (NDP) identification of agriculture as primarily an economic activity in rural areas with the potential to create one million jobs by 2030 (NCP, 2012). The positive earnings are indications that the smallholder enterprise development has the potential for enrichment as well as ensuring long-term improvement of livelihood opportunities for smallholders.

\subsection{Market Survey Results}

The ability to access and utilise markets in selling produce helps in enhancing farmer livelihoods. For farmers to be able to use markets efficiently, it is important for them to know the marketing environment and the requirements thereof. Two types of markets exist for sweet potatoes namely, the formal and informal markets. Both types of markets indicated a willingness to obtain sweet potatoes from the smallholder farmers. The informal markets are mainly made up of the hawkers while the formal markets comprise of the retailers and the National Fresh Produce Markets (NFPM) (Figure 2). The informal markets are easily accessible, consume relatively small quantities in spite of relatively high prices offered at times, and are willing to buy in bulk with no packaging required. Some positive characteristics to consider for informal markets is that, these markets 
provide a significant income opportunity for emerging sweet potato farmers due to their limited standards requirements and absence of packaging-related costs.

The formal markets include urban supermarkets such as Fruit and Veg City (FVC), Pick n Pay, Spar, Checkers and Shoprite. Other players in the formal markets include wholesale outlets and fresh produce retailers in municipal markets. Formal markets are characterised by well-defined value chain systems and are very strict on quality of the produce, traceability along the supply chain and demand high volumes of supply as well as require consistency in supply. Formal markets can offer sweet potato farmers prospects for growth because they order sweet potatoes in bulk and provide an opportunity to have a consistent source of income, with clear market signals which come directly from traders.

The market survey revealed that the sweet potato market, in terms of volumes sold is dominated by National Fresh Produce markets, while hawkers consume the least quantities of sweet potatoes produced in the country (Figure 2). Thus, informal markets may be attractive initially to sweet potato producers, but as production increases, National Fresh Produce markets become more attractive because they absorb large quantities at a time.

Table 2. The distribution of sweet potato volumes among formal and informal traders

\begin{tabular}{ll}
\hline Market Type & Share of marketed volumes \\
\hline Retailers & $28 \%$ \\
Hawkers & $20 \%$ \\
National Fresh Produce Markets & $52 \%$ \\
\hline
\end{tabular}

Source: Market Survey, ARC-VOPI (2013/2014).

Table 3 shows the highest and lowest volumes of sweet potatoes that are marketed through the Johannesburg and Tshwane markets. Highest volumes are sold between April and June because sweet potatoes enjoy warm conditions in production, therefore are mostly produced in the summer season. Only a few frost free areas can produce sweet potatoes in winter, the reason why lowest volumes are sold between October and December. The average prices offered in the markets was $\mathrm{R} 3 / \mathrm{kg}$.

Table 3. Average volumes of sweet potato marketed through the main fresh produce markets

\begin{tabular}{ll}
\hline NFP Markets & Highest marketed volumes \\
\hline & Apr.-Jun. \\
Johannesburg & $2200 \mathrm{t} /$ month \\
Tshwane & $1600 \mathrm{t} /$ month \\
\hline
\end{tabular}

Source: Market Survey, ARC-VOPI (2013/2014).

Several cultivars were marketed in various channels among which are Blesbok, Bosbok, Impilo, Bophelo, Ndou and Monate. An analysis of the volumes of the cultivar most commonly traded on a monthly basis in the formal markets indicated that Blesbok is more traded than the other sweet potato cultivars (Table 4). This can be attributed to the fact that sweet potato in South Africa is largely produced by commercial farmers who may be interested in the cultivar due to its high-yielding attributes. However, this can also serve as an opportunity to introduce and promote the cultivation of the highly nutritious orange-fleshed sweet potato cultivars developed and promoted by ARC such as Impilo and Bophelo. It is also important to note that other cultivars such as Ribbok and Koedoe are sold in the market although the survey did not find an indication of such.

Table 4. Market share of the common sweet potato cultivars in the formal markets

\begin{tabular}{ll}
\hline Sweet Potato Cultivar & Market Share \\
\hline Monate & $15 \%$ \\
Impilo & $6 \%$ \\
Ndou & $7 \%$ \\
Bosbok & $5 \%$ \\
Blesbok & $67 \%$ \\
\hline
\end{tabular}

Source: Market Survey, ARC-VOPI (2013/2014). 


\subsection{Market Survey Results}

There are options for intervention based on market types and farmer resources. Tracing the upstream value chain linkages shows that a small number of commercial farmers dominates agricultural product supplies to the formal market. Both the formal and informal markets are available for the marketing of the sweet potato produce. The informal market constitutes an important component in the economic activities of the rural communities as it is readily accessible. The formal market offers high economic returns although characterised by high quality demands as well as consistency in produce supplies, which the majority of the smallholder farmers are unable to meet with external support. Although without strict quality requirements and specifications, informal markets offer little returns due to low product prices. To utilise the formal market, farmers will require infrastructural and technical support to increase area under sweet potato production, raise productivity and quality. In addition, farmers need to be helped to manage their farm resources effectively and improve their business management skills through training to become consistent net sellers of sweet potatoes in the market. Farmers in the enterprise development projects will benefit from taking an aggressive approach in adopting better improved sweet potato cultivars supplied by the ARC. Such support will substantiate the perception by IFAD (2011) that with the right policies and incentives in place, smallholders can consider long-term prioritisation of sustainable techniques.

\subsection{Sweet Potato Pricing}

An analysis of the national sweet potato seasonal price changes was done and the findings are presented in Figure 1. The sweet potato prices are dependent on supply and demand forces. Prices are low during peak harvesting time (April to July). However, prices are high immediately after winter. Early summer plantings need to be encouraged or targeted to fetch high returns from the market. The smallholder farmers situated in frost-free areas can also be encouraged to take advantage of the high revenues associated with late plantings and production.

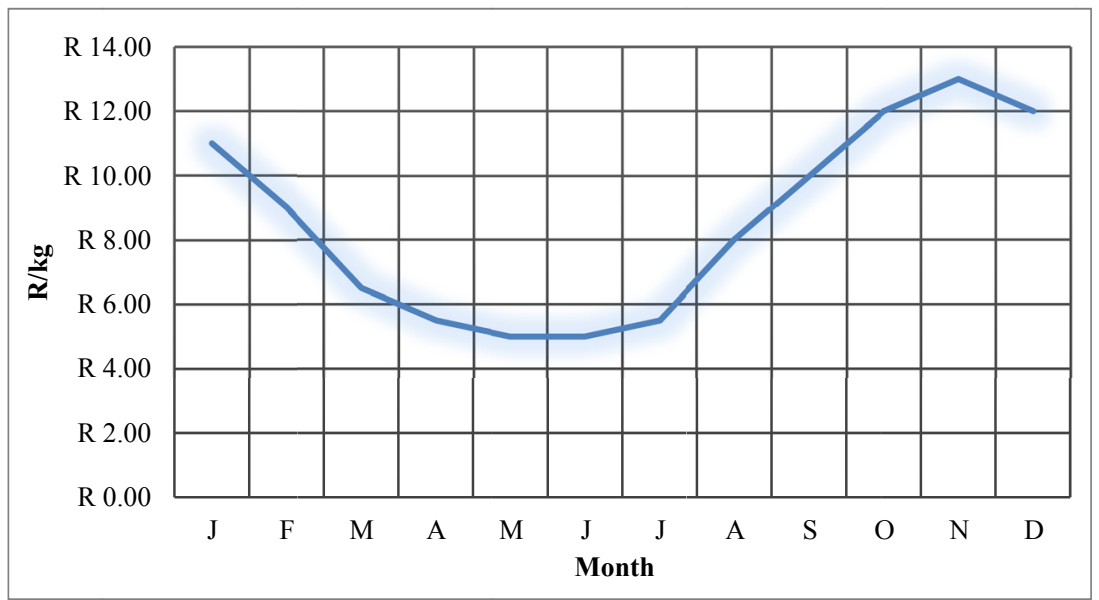

Figure 1. Sweet potato average prices for the 2013/2014 season

Source: Market Survey, ARC-VOPI (2013/2014).

\subsection{Production Costs}

Sweet potato growers (growers of the tubers) incur a variety of production costs among which are the expenses for inputs such as fertilisers, vines, chemicals (Table 5). Other costs include the cost of electricity for irrigation as well as water. Sweet potato production is labour intensive for the smallholder farmers (amounting to $22 \%$ of the total production costs) especially during the planting and harvesting times. Thus, the establishment of these enterprises have a great potential to create jobs within the communities where they are situated, consequently improving their livelihoods. 
Table 5. Average proportion of each type of production costs for sweet potato growers

\begin{tabular}{ll}
\hline Variable & Proportion of the total running costs \\
\hline Vines & $27 \%$ \\
Labour & $22 \%$ \\
Water & $7 \%$ \\
Electricity & $5 \%$ \\
Tractor Running costs & $11 \%$ \\
Chemicals & $9 \%$ \\
Fertiliser & $19 \%$ \\
\hline
\end{tabular}

Source: Field survey data (2013/14).

\subsection{Profitability of Sweet Potato Vines (Gross Margin)}

The production and profitability of the enterprises were calculated using farm records data from project beneficiaries and data from ARC trials. Table 6 shows the profitability of a few selected vine nurseries in different locations, for the production of the 2013/14 season. The nurseries have a Gross Margin of at least R180,000 per hectare. This is a significantly high economic gain to improve the livelihoods of the beneficiaries together with ensuring their food security. Gross margin values for enterprise development beneficiaries are within the same range with those from ARC trials.

Table 6. Profitability of sweet potato vines (Gross Margin)

\begin{tabular}{llll}
\hline GM Calculation & Vine Grower Tzaneen/Ha & Vine Grower Brits/Ha & ARC Nursery/Ha \\
\hline Gains from Investment & R 359 473 & R 313 575 & R 360 000 \\
Cost of Investment & R140 082 & R132 978 & R133 343 \\
Gross Margin & R219 394 & R180 597 & R 226 657 \\
\hline
\end{tabular}

Source: Field survey data (2013/14).

\subsection{Profitability of Sweet Potatoes (Gross Margin)}

Table 7 shows the profitability of the sweet potatoes (tubers) of a selected few of the already established growers. In order to predict the profitability of the enterprises in the future, gross margins were calculated for the 2013/14 production season. Both the gross income and production costs were based on real figures as reflected in the records kept by the growers. The enterprises showed positive economic returns to investment. An average Gross Margin of R47,000 is realised by the growers. Generally, the price of sweet potato was R5/kg. However, due to differences in supply volumes to different markets, the average price of the produce also differed, with low prices associated with places where supply volumes were high. For instance, the average price for sweet potatoes from Roodeplaat was $50 \%$ less than that in other provinces i.e. R2.40/kg.

Table 7. Profitability of sweet potatoes (Gross Margin)

\begin{tabular}{lllll}
\hline Site & $\begin{array}{l}\text { Vhembe-Thulamela } \\
\text { LIMPOPO }\end{array}$ & $\begin{array}{l}\text { Capricorn-Machaba } \\
\text { LIMPOPO }\end{array}$ & $\begin{array}{l}\text { Uitenhage } \\
\text { EASTERN CAPE }\end{array}$ & $\begin{array}{l}\text { Roodeplaat } \\
\text { ARC-VOPI GAUTENG }\end{array}$ \\
\hline Yield & $16.5 \mathrm{t} / \mathrm{ha}$ & $15.8 \mathrm{t} / \mathrm{ha}$ & $30.3 \mathrm{t} / \mathrm{ha}$ & $30 \mathrm{t} / \mathrm{ha}$ \\
\hline Average Price & $\mathrm{R} 5 / \mathrm{kg}$ & $\mathrm{R} 5 / \mathrm{kg}$ & $\mathrm{R} 3 / \mathrm{kg}$ & $\mathrm{R} 2.40 / \mathrm{kg}$ \\
Gross Income/ha & $\mathrm{R} 82,500$ & $\mathrm{R} 79,000$ & $\mathrm{R} 90,900$ & $\mathrm{R} 72,370$ \\
Total Variable Costs & $\mathrm{R} 49,400$ & $\mathrm{R} 31,400$ & $\mathrm{R} 36,750$ & $\mathrm{R} 25,262$ \\
Gross Margin/ha & $\mathrm{R} 33,100$ & $\mathrm{R} 47,600$ & $\mathrm{R} 47,108$ \\
\hline
\end{tabular}

Sweet potato vine and root production are both profitable. Vine production is more profitable as compared to root production, but its production requires larger investment than root production and the vines require constant monitoring. Although farmers receive external support with regard to infrastructural development and improvement, vine growers are encouraged to make a sliding $20 \%$ contribution towards the purchase of the vines from their second year of production onwards so as to eliminate dependency syndrome while ensuring sustainability of the established enterprises. That is, this contribution increases by $20 \%$ each successive year 
while external contribution decreases at the same rate. The strategy will also be implemented with the sweet potato growers after evaluating their potential and capacity to contribute towards input costs. A challenge associated with vine production is that, marketing vines to smallholder farmers is not easy as the majority of smallholder farmers often depend on plant material from the previous season. Thus, vine growers should intend to produce high quality vines and also enter the market for selling to commercial sweet potato growers. However, there is a chance that smallholder farmers will see the need to buy planting material once they realise the difference in yield as influenced by source of plant material.

Working with smallholders and supporting them so they can become the developers of sustainable solutions has been identified as the best way to boost food production and improve livelihoods in an environmentally sustainable way (IFAD, 2011). The necessary institutional support needful for the poor farmers to change their practices calls for intervention by the government and other development organisation through relevant policies. The already established agricultural policies can tap from these research finding and formulate strategies to capacitate and improve the potential of the smallholders. Since the National Food and Nutrition Security Policy anchors on building on existing initiatives and systems, and to putting in place mechanisms that ensure better coordination (DAFF, 2013), the enterprise development project paves a way for such a strong pathway to sustainable food production, improved market access, access to production inputs and the promotion of food security. This is important because elsewhere, research has also shown that smallholder farmers are willing and able to change how they do business when guided by coherent policies and fair incentives (IFAD, 2011).

\section{Conclusion}

Sweet potato enterprises can potentially improve food security among rural poor in South Africa. Producers of vines and sweet potatoes can get a significant amount of income from farming sweet potato. Smallholder producers have an immense potential to contribute to feeding the nation, communities and the world. This is more urgent due to the rising need to produce more than $70 \%$ additional food by 2050 to feed the growing population. The foundation of a solution to a worldwide challenge are local approaches to food security and poverty reduction. These approaches can encompass intensifying simple production methods. The realisation of the smallholder farmer potential is only through investments in infrastructure, training, market information, access to finance and access to markets are key.

The high percentage of production costs taken by labour implies a greater potential of employment creation through sweet potato vine nurseries and growers, implying an improvement in food security to the community members, even those who are not directly involved in production. The establishment of sweet potato enterprises will directly lead to food and income generation for the entrepreneurs, indirectly it will have far reaching benefits including the potential to aid in employment creation, rural development, food security and curbing malnutrition and reducing rural poverty.

On the basis of the gross Margin analysis and market survey results, it can be concluded that investing in sweet potato production is a profitable venture and can potentially improve food security among the rural poor in South Africa. Smallholder farmers can utilise both formal and informal markets for selling sweet potatoes. In supplying formal markets, farmers need to produce relatively large amounts and should produce high quality products in order to stand competition. Informal markets are flexible in terms of quality and can be easily accessed by smallholder farmers.

The crucial need for the South African smallholder farmers is to improve access to high value formal markets. It will be helpful to raise awareness among rural people of the benefits of sweet potatoes either in producing for sale or purchasing them for home consumption. The ease with which sweet potato can be produced and managed together with its inherent high nutritive value serve as strong reasons for promoting the commercial cultivation of the crop by the smallholder farmers. The challenge of inadequate access to knowledge and resources to make optimal choices for nutritious and safe diets can be addressed through the promotion of crops with high nutritive value such as sweet potato. There is a strong need to train the smallholder farmers on how to improve productivity and on entrepreneurial skills. Since no one size fits all when addressing challenges faced by farmers, individual cases among the smallholder farming community need to be treated accordingly. Lastly, smallholder farmers producing small quantities need to be encouraged to engage in collective supply to markets so as to reduce on marketing costs and enhance bargaining power.

\section{Recommendations}

There is need for a supportive enabling environment for farmers to realise their full potential towards commercial production. The access by policymakers to a range of tools to unleash the potential of smallholder producers to build sustainable livelihoods while simultaneously contributing to economic development and food 
security should form the anchor of promoting smallholder commercial production. The incorporation of strong research in support of sweet potato production provides backup for the sustainability of the enterprises especially research that is inclined towards disease-tolerant or resistant cultivars as well as those that are highly nutritious like the orange-fleshed ARC-VOPI produced Bophelo cultivar.

The intervention offers valuable lessons for policy directed at commercialising smallholders. While policies supporting smallholder farming and food security can influence positive institutional arrangements in support of the producers, multi-stakeholder mobilisation and engagement is critical especially involving the key value chain players in the formal markets. This is key because smallholders can hardly produce at commercial levels owing to their inherent poor resource base among other challenges. Successful joint ventures can boost both agricultural productivity as well as increased market access. Farmers should not be exclusively linked to formal markets, but the development of informal markets should also receive attention as the later still plays a significant role among the rural communities including employment creation.

\section{References}

Abdu-Raheem, K. A., \& Worth, S. H. (2011). Household food security in South Africa: Evaluating extension's paradigms relative to the current food security and development goals. South African Journal of Agriculture Extension, 39(2), 91-103.

Altman, M., Hart, T. G. B., \& Jacobs, P. T. (2010). Household food security status in South Africa. Agrekon, 48(4), 345-361. https://doi.org/10.1080/03031853.2009.9523831

Baiphethi, M. N., \& Jacobs, P. T. (2009). The contribution of subsistence farming to food security in South Africa. Agrekon, 48(4), 459-482. https://doi.org/10.1080/03031853.2009.9523836

Cloete, P. C., \& Idsardi, E. (2012). Bio-fuels and food security in South Africa: The role of indigenous and traditional food crops. Selected paper prepared for presentation at the International Association of Agricultural Economists (IAAE) Triennial Conference, Foz do Iguaçu, Brazil, August 18-24, 2012.

DAFF (Department of Agriculture Forestry and Fisheris). (2013). National Policy on Food and Nutrition Security for the Republic of South Africa (August, 2013).

Drimie, S. (2016). Understanding South African food and agricultural policy: Implications for agrifood vale chains, regulation, and formal and informal livelihoods. Working Paper 39. Cape Town: PLAAS, UWC and Center of Excellence on Food Security.

FANRPAN (Food, Agriculture and Natural Resources Policy Analysis Network). (2006). Food Insecurity in Sekhukhune. Fighting Hunger: Linking Information to Action. Food Insecurity and Vulnerability Information Management System, Food Security Information Brief 1, July, 2006.

IFAD (International Fund for Agricultural Development). (2011). Sustainable smallholder agriculture: Feeding the world, protecting the planet. Rome, Italy.

Laurie, S. (2004). Sweet potato cultivars. Guide to sweet potato production in South Africa (pp. 57-68). ARC-Roodeplaat Vegetable and Ornamental Plants Institute.

Mistry, R. (2014). Hidden hunger strips away dignity, perpetuates inequality and destroys South Africans' potential to prosper. Retrieved November 10, 2014, from http://www.oxfam.org/en/pressroom/pressreleases

Reardon, T. (2005). Retail companies as integrators of value in developing countries: Diffusion, procurement system change, and trade development effects. Frankfurt: GTZ. Retrieved November 3, 2017, from https://www2.giz.de/dokumente/bib/06-1002.pdf

Van der Berg, S. (2006). Public spending and the poor since the transition to democracy. In Bhorat \& Kanbur (Eds.), Poverty and Policy in Post-Apartheid South Africa (pp. 201-231). Human Sciences Research Council Press, Pretoria.

\section{Copyrights}

Copyright for this article is retained by the author(s), with first publication rights granted to the journal.

This is an open-access article distributed under the terms and conditions of the Creative Commons Attribution license (http://creativecommons.org/licenses/by/4.0/). 